\title{
Fine-Needle Aspiration Cytology of Salivary Gland Tumors Before the Milan System: Ten Years of Experience at a Tertiary Care Center in Turkey
}

\author{
Milan Sistemi Öncesi Tükürük Bezi Tümörlerinin İnce İğne Aspirasyon \\ Sitolojisi: Türkiye'de Bir Üçüncü Basamak Merkezin On Yıllık Deneyimi
}

\author{
Selcuk YILDIZ $\odot$, Lutfu SENELDIR $\odot$, Cigdem TEPE KARACA $\odot$, Sema ZER TOROS $\odot$
}

Ethics Committee Approval: This study was approved by Haydarpasa Numune Training and Research Hospital Ethics Committee for Clinical Studies, 27 May 2020.

Conflict of interest: The authors declare that they have no conflict of interest.

Funding: None.

Informed Consent: Not applicable.
Cite as: Yildiz S, Seneldir L, Tepe Karaca C, Zer Toros S. Fine-needle aspiration cytology of salivary gland tumors before the milan system: Ten years of experience at a tertiary care center in Turkey. Medeni Med J. 2021;36:233-40.

\begin{abstract}
Objective: The role of fine-needle aspiration cytology (FNAC) is well established for preoperative evaluation of patients with salivary gland lesions. However, the lack of a uniform system for salivary gland FNAC has limited its effectiveness. In recent years, the Milan System for Reporting Salivary Gland Cytopathology (MSRSGC) has been in use around the world to report the cytology results. We aimed to investigate the efficacy and accuracy of FNAC examined according to pre-MSRSGC era dichotomous benign/malignant classification in salivary gland tumors.

Methods: Patients who underwent surgery between January 2011 and December 2020 due to major salivary gland tumors were retrospectively analyzed. Two hundred and four patients were included in the analysis. Preoperative FNAC results and final histopatological diagnoses were grouped as benign or malignant. Final histopatological diagnoses were compared with the preoperative FNAC results. Also, sensitivity, specificity, and accuracy of the preoperative FNAC results, as well as the agreement between both tests were investigated.

Results: The sensitivity, specificity, accuracy, positive and negative predictive values of the preoperative FNAC for the diagnosis of malignancy were $59.09 \%, 97.85 \%, 93.75 \%, 76.47 \%$, and $95.29 \%$, respectively. There was a moderate agreement between the preoperative FNAC results and final histopatological diagnoses.

Conclusion: The accuracy of the preoperative FNAC and the information given about malignancy risk are the most important criteria for patient management and decision-making. The MSRSGC, which consists of a six-tiered classification rather than a dichotomous "yes/no" system, may contribute to patient management and decision-making by increasing the efficacy and accuracy of FNAC.
\end{abstract}

Keywords: Fine-needle aspiration cytology, Milan system, parotid gland, salivary gland, submandibular gland

Öz

Amaç: Tükürük bezi lezyonları olan hastaların preoperatif değerlendirilmesinde ince iğne aspirasyon sitolojisinin (iïAS) rolü iyi bilinmektedir. Ancak tükürük bezi IïAS için tek tip bir sistemin olmaması etkinliğini sınırlamıştır. Son yıllarda tükürük bezi sitopatolojisini raporlamak için oluşturulan Milan sistemi (MS) dünya çapında kullanılmaktadır. Çalışmamızda tükürük bezi tümörlerinin MS öncesi ikili benign/malign sınıflamasına göre incelenen IİAS sonuçlarının etkinliğini ve doğruluğunu araştırmayı amaçladık. Yöntem: Ocak 2011-Aralık 2020 tarihleri arasında majör tükürük bezi tümörü nedeniyle ameliyat edilen hastalar retrospektif olarak tarandı. Calıșmaya 204 hasta dahil edildi. Preoperatif iïAS sonuçları ve nihai histopatolojik tanılar benign ve malign olarak gruplandırıldı. Nihai histopatolojik tanılar, preoperatif iïAS sonuçları ile karşılaştırıldı ve preoperatif IİAS sonuçlarının duyarııı̆̆ı, özgüllüğü, doğruluğu ve her iki test arasındaki uyum araștırıldı.

Bulgular: Malignite tanısı için preoperatif ïAS'nin duyarlılığı \%59,09, özgüllüğü \%97,85, doğruluğu $\% 93,75$, pozitif prediktif değeri \%76,47 ve negatif prediktif değeri \%95,29 idi. Preoperatif iïAS sonuçları ile nihai histopatolojik tanı arasında orta derecede bir uyum vardı.

Sonuç: Preoperatif iïAS'nin doğruluğu ve malignite riski hakkında verdiği bilgiler hasta yönetimi ve karar vermede en önemli kriterlerdir. Ikili bir "evet/hayır" sisteminden ziyade altı katmanlı bir sınıflandırmadan oluşan MS, IIAS'nin etkinliğini ve doğruluğunu artırarak hasta yönetimine ve karar vermeye katkıda bulunabilir.

Anahtar kelimeler: ince iğne aspirasyon sitolojisi; Milan sistemi; parotis bezi; tükürük bezi; submandibular bez
Received: 13 July 2021

Accepted: 31 August 2021

Online First: 30 September 2021

Corresponding Author:

S. Yildiz

ORCID: 0000-0002-2820-8888

Haydarpaşa Numune Training and Research Hospital, Department of Otorhinolaryngology and Head and Neck Surgery, İstanbul, Turkey

selcukyildiz60@hotmail.com

L. Seneldir
ORCID: 0000-0003-1744-1710
C. Tepe Karaca
ORCID: 0000-0002-5565-1711
S. Zer Toros
ORCID: 0000-0003-3125-732X
Haydarpaşa Numune Training and
Research Hospital,
Department of Otorhinolaryngology
and Head and Neck Surgery,
İstanbul, Turkey

(c) Copyright Istanbul Medeniyet University Faculty of Medicine. This journal is published by Logos Medical Publishing. Licenced by Creative Commons Attribution-NonCommercial 4.0 International (CC BY-NC 4.0) 


\section{INTRODUCTION}

Tumors of salivary glands constitute almost three percent of all head and neck neoplasms ${ }^{1}$. Approximately $80 \%$ of salivary gland masses are benign $^{2}$. Pleomorphic adenoma (PMA) is the most common benign and mucoepidermoid carcinoma is the most common malignant tumor of salivary glands ${ }^{3}$. Furthermore, metastatic tumors, inflammatory conditions, and lymphoma may induce formation of masses in salivary glands $s^{4,5}$.

Characterized by complex clinical and pathologic features, salivary gland tumors are neoplasms that comprise a wide variety of morphologic and cellular features ${ }^{3}$. The clinical differentiation between benign and malignant masses is not simple because of similar manifestations of these tumors. There are only a few clinical symptoms that suggest malignancy ${ }^{6}$. Therefore, further tests are required to make diagnosis. For decades, fine-needle aspiration cytology (FNAC) has been used for the assessment of salivary gland masses. FNAC is a precious method in the preoperative assessment of head and neck neoplasms ${ }^{5}$. FNAC is safe, easy-to-apply, minimally invasive, and inexpensive technique ${ }^{7}$. The FNAC technique is associated with low rates of complications and morbidity ${ }^{8}$. Complications such as bleeding, facial nerve damage, and fibrosis have been rarely reported ${ }^{9}$.

Histopathological and cytologic diagnoses of salivary gland tumors are based on the pathologic classification of the World Health Organization ${ }^{10}$. However, this dichotomous benign/malignant classification of the preoperativeFNACexamination has no determined range of malignancy rate which causes difficulties for patient management and decision-making in the preoperative period. In the current literature, the specificity and sensitivity rates of the preoperative FNAC examined according to pre-MSRSGC era dichotomous benign/malignant classification have been repoprted as $56-100 \%$ and $57-98 \%$, respectively ${ }^{11,12}$. The heterogeneous histology of salivary glands has been shown as the reason for the discussions about the specificity and sensitivity of the preoperative FNAC results reported in many studies ${ }^{13}$. Cytologic examination and reporting of salivary gland lesions can be extremely difficult, especially in the absence of standardization and guidelines ${ }^{14,15}$. Therefore, it has been argued that more systematic diagnostic criteriaareneeded ${ }^{16,17}$. In line with this requirement, the American Society of Cytopathology and the International Academy of Cytology aimed to standardize the Milan System for Reporting Salivary Gland Cytopathology (MSRSGC) developed by an international task team composed of pathologists and otolaryngologists ${ }^{15,18,19}$. Thus, it was aimed to improve the communication between pathologists and physicians, and provide guidance through the best available therapeutic decisions $^{15,19}$.

Our aim is to investigate the efficacy and accuracy of the preoperative FNAC examined according to pre-MSRSGC era dichotomous benign/malignant classification in major salivary gland tumors and the relevant effective factors.

\section{MATERIAL and METHODS}

This study was conducted in a retrospective, cross-sectional, and register-based pattern. The study was approved by the institutional administration (approval number: 62977267000-6168) and conducted in accordance with the ethical principles for medical research involving human subjects outlined in the Declaration of Helsinki. Informed consent was waived due to the retrospective design of the study. Patients who underwent surgery due to major salivary gland tumors at the otorhinolaryngology department of a large tertiary care academic center from January 2011 to December 2020 were analyzed retrospectively. Patients without preoperative ultrasonography (USG), with a 
S. Yildiz et al. Fine-Needle Aspiration Cytology of Salivary Gland Tumors Before the Milan System: Ten Years of Experience at a Tertiary Care Center in Turkey

nondiagnostic preoperative FNAC result, and with a preoperative FNAC result obtained from another healthcare center were excluded. Age, sex, tumor side, tumor size as measured by USG, sonographic features of tumors, preoperative FNAC results, and final histopathological diagnoses were recorded.

In our tertiary care center, FNAC is performed in the outpatient clinic with USG guidance. The aspiration material is sprayed on at least three to four glass coverslips, spread, fixed with alcohol, and submitted to the pathology laboratory. Direct smears are stained using the Papanicolaou technique. Over the last decade, cytologic examinations havebeen performed byexperienced cytologists according to pre-MSRSGC era dichotomous benign/malignant classification.

We investigated, and compared the sensitivity, specificity, negative predictive value (NPV), positive predictive value (PPV), accuracy, and consistency rates between the preoperative FNAC results, and the final histopathological diagnoses. These parameters were further investigated according to the most common tumor types using the same parameters. The agreement between the preoperative FNAC results and the final histopathological diagnoses was investigated across the study groups formed according to the sonographic features and tumor sizes measured.

\section{Statistical analysis}

For statistical analyses, the Number Cruncher Statistical System software (Kaysville, Utah, USA) was used. Descriptive statistical methods (mean, standard deviation, median, frequency, ratios, and minimum and maximum values) were used to evaluate the study data. Fisher's exact test was used to compare qualitative data. To determine the cut-off values for parameters, measures of diagnostic accuracy (sensitivity, specificity, PPV, and NPV) were used. Diagnostic accuracy tests (sensitivity, specificity, PPV, and NPV) were used to evaluate the agreement between the preoperative FNAC results and the final histopathological diagnoses. The level of statistical significance level was defined as $\mathrm{p}<0.05$.

\section{RESULTS}

Two hundred and eleven patients were retrospectively analyzed. One patient without preoperativeUSG, threepatients with nondiagnostic FNAC results, and three patients with preoperative FNAC results from another healthcare center were excluded from the study. As a result, a total of 204 patients were included. Of the participants, 50.5\% $(n=103)$ were female and $49.5 \%(n=101)$ were male. The mean age of the study participants was $49.14 \pm 14.47$ (range: 13-83) years. Tumors were on the right side in 107, and on the left side in 93, and bilateral in four patients. Thus, a total of 208 tumors were evaluated.

USG measurements showed that the mean tumor size was $24.50 \pm 11.00$ (range: 7-61, median: 22 ) $\mathrm{mm}$. When the sonographic features of the tumors were evaluated, it was found that $21.2 \%$ $(n=44)$ of them were cystic and $78.8 \%(n=164)$ were hypoechoic and solid (Table 1 ). When the preoperative FNAC results were evaluated, it was observed that $91.8 \%(n=191)$ of the patients were

Table 1. Evaluation of the preoperative accuracy rates of FNAC according to tumor sizes measured and sonographic features.

\begin{tabular}{|c|c|c|c|c|}
\hline & & \multicolumn{2}{|c|}{$\begin{array}{c}\text { Preoperative FNAC } \\
\text { accuracy }\end{array}$} & \multirow[b]{2}{*}{$\mathbf{p}$} \\
\hline & & $\begin{array}{l}\text { Concordant } \\
(n=195)\end{array}$ & $\begin{array}{l}\text { Discordant } \\
(n=13)\end{array}$ & \\
\hline \multirow[t]{2}{*}{$\begin{array}{l}\text { Tumor size; } \\
\text { n (\%) }\end{array}$} & $\begin{array}{l}<20 \mathrm{~mm} \\
\geq 20 \mathrm{~mm}\end{array}$ & $\begin{array}{l}78(98.7) \\
117(90.7)\end{array}$ & $\begin{array}{l}1(1.3) \\
12(9.3)\end{array}$ & ${ }^{*} 0.019$ \\
\hline & $\begin{array}{l}\text { Min-Max } \\
\text { (Median) } \\
\text { Mean } \pm \text { SD }\end{array}$ & $\begin{array}{l}7-61(22) \\
24.32 \pm 11.12\end{array}$ & $\begin{array}{l}11-41(28) \\
27.15 \pm 8.95\end{array}$ & \\
\hline \multirow{2}{*}{$\begin{array}{l}\text { Sonographic } \\
\text { feature }\end{array}$} & Cystic & $34(77.3)$ & $10(22.7)$ & ${ }^{* *} 0.001$ \\
\hline & $\begin{array}{l}\text { Hypoechoic, } \\
\text { solid }\end{array}$ & $161(98.2)$ & $3(1.8)$ & \\
\hline
\end{tabular}

Fisher's Exact Test, ${ }^{*} p<0.05,{ }^{* *} p<0.01$

FNAC: Fine-needle aspiration cytology, USG: Ultrasonography 
diagnosed with a benign tumor and $8.2 \%(n=17)$ with a malignant tumor. When the final histopathological diagnoses were examined, $89.4 \%(n=186)$ and $10.6 \%(n=22)$ of the patients were found to have benign and malignant tumors, respectively. Of the 186 patients with final histopathologic diagnosis of benign tumor, the preoperative FNAC results were reported as benign and malignant in 182 and 4 patients, respectively. Of the 22 patients with final histopathologic diagnosis of malignant tumor, 13 were found to have a malignant tumor whereas 9 patients had a benign tumor based on the the examination results of the preoperative FNAC. Accordingly, the sensitivity, specificity, accuracy, PPV, and NPV of the preoperative FNAC for the diagnosis of malignancy were 59.09\%, 97.85\%, 93.75\%, 76.47\% and 95.29\%, respectively (Table 2).

Table 2. Comparison of the preoperative FNAC results and final histopathological diagnosis.

\begin{tabular}{|c|c|c|c|c|}
\hline & & Final histo & pathologic & diagnosis \\
\hline & & $\begin{array}{l}\text { Benign } \\
\text { n (\%) }\end{array}$ & $\begin{array}{l}\text { Malignant } \\
\text { n (\%) }\end{array}$ & $\begin{array}{l}\text { Total } \\
\text { n (\%) }\end{array}$ \\
\hline Preoperative & Benign & $182(87.5)$ & $9(4.3)$ & 191 (91.8) \\
\hline FNAC Results & Malignant & $4(1.9)$ & $13(6.3)$ & $17(8.2)$ \\
\hline & Total & $186(89.4)$ & $22(10.6)$ & $208(100)$ \\
\hline & Sensitivity & $59.09 \%$ & & \\
\hline & Specificity & $97.85 \%$ & & \\
\hline Positive Prec & ictive Value & $76.47 \%$ & & \\
\hline Negative Prec & ictive Value & $95.29 \%$ & & \\
\hline & Accuracy & $93.75 \%$ & & \\
\hline
\end{tabular}

FNAC: Fine-needle aspiration cytology

According to both the preoperative FNAC results and the final histopatological diagnoses, PMA was the most common tumor type, followed by Warthin tumor (WT). The diagnostic compatibility of the preoperative FNAC results and the final histopathological diagnoses was investigated in terms of the most common tumor groups encountered in clinical practice. For PMA the sensitivity (94.06\%), specificity (94.34\%), accuracy (94.23\%). PPV (94.06\%), and NPV (94.39\%) of the test were determined (Table 3). Besides, for WT, the sensitivity (81.25\%), specificity (91.67\%), accuracy (88.46\%), PPV (81.25\%), and NPV $(91.67 \%)$ of the test are shown in Table 4.

A statistically significant difference was found

Table 3. Comparison of the preoperative FNAC results and final histopathological diagnosis for PMA.

\begin{tabular}{|c|c|c|c|c|}
\hline & & \multicolumn{3}{|c|}{ Final histopathologic diagnosis } \\
\hline & & $\begin{array}{l}\text { non-PMA } \\
\text { n }(\%)\end{array}$ & $\begin{array}{l}\text { PMA } \\
\text { n (\%) }\end{array}$ & $\begin{array}{l}\text { Total } \\
\text { n (\%) }\end{array}$ \\
\hline \multirow{3}{*}{$\begin{array}{l}\text { Preoperative } \\
\text { FNAC Results }\end{array}$} & Non-PMA & 101 (48.6) & $6(2.9)$ & $107(51.4)$ \\
\hline & PMA & $6(2.9)$ & 95 (45.7) & 101 (48.6) \\
\hline & Total & $107(51.4)$ & 101 (48.6) & $208(100)$ \\
\hline & Sensitivity & $94.06 \%$ & & \\
\hline & Specificity & $94.39 \%$ & & \\
\hline Positive Prec & ictive Value & $94.06 \%$ & & \\
\hline Negative Prec & ictive Value & $94.39 \%$ & & \\
\hline & Accuracy & $94.23 \%$ & & \\
\hline
\end{tabular}

FNAC: Fine-needle aspiration cytology, PMA: Pleomorphic adenoma

Table 4. Comparison of the preoperative FNAC results and final histopathological diagnosis for WT.

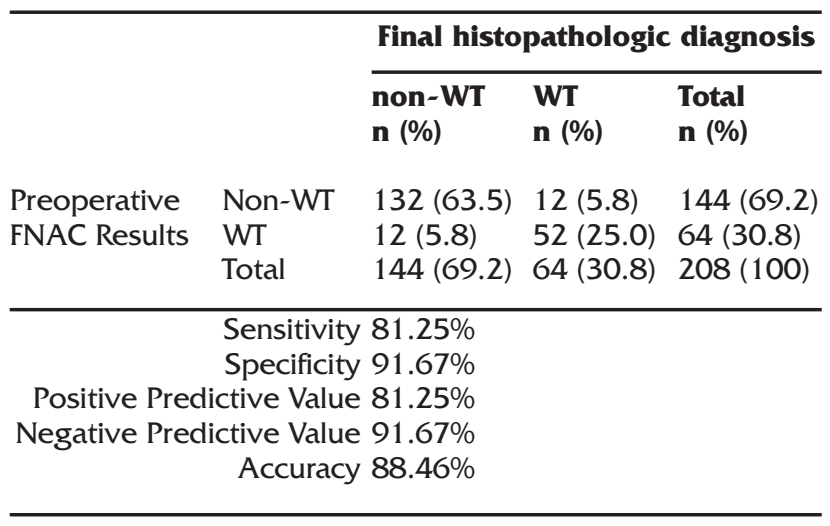

FNAC: Fine-needle aspiration cytology, WT: Warthin tumor

Table 5. Diagnostic categories of the MSRSGC with the risk of malignancy.

\begin{tabular}{ll}
\hline Diagnostic categories & ROM \\
1) Nondiagnostic & 25 \\
2) Non-neoplastic & 10 \\
3) AUS & 20 \\
4a) Neoplasm-benign & $<5$ \\
4b) Neoplasm-SUMP & 35 \\
5) Suspicious for malignancy & 60 \\
6) Malignant & $>90$
\end{tabular}

AUS: atypia of undetermined significance MSRSGC: Milan system for reporting salivary gland cytopathology, ROM: risk of malignancy; SUMP: uncertain malignant potential. 
S. Yildiz et al. Fine-Needle Aspiration Cytology of Salivary Gland Tumors Before the Milan System: Ten Years of Experience at a Tertiary Care Center in Turkey

between the preoperative FNAC results and final histopathological diagnoses according to the tumor size measured ( $p=0.019)$ (Table 1). The agreement between the preoperative FNAC results and final histopathological diagnoses was lower for tumors with a diameter of $\geq 20 \mathrm{~mm}$. A statistically significant difference was found for concordance between the preoperative FNAC results and final histopathological diagnoses according to the sonographic features of the tumors $(p=0.001)$ (Table 1$)$. The agreement between the preoperative FNAC results and final histopathological diagnoses was low in terms of cystic tumors.

\section{DISCUSSION}

For the diagnosis of malignancy, there was a moderate agreement between the preoperative FNAC results, which were examined according to pre-MSRSGC era dichotomous benign/malignant classification, and final histopathological diagnoses.

Salivary gland tumors are more common in males ${ }^{20}$. Benign salivary gland tumors are most seen in the fifth decade of life, and malignant tumors occur mostly in the sixth decade ${ }^{20,21}$. In the present study, the distribution of tumors among females and males was found to be quite similar. On average, all patients with malignant of benign lesions included in the study were in their fifth decade of their lives.

The most common histopathological type of salivary gland tumors is PMA, followed by $\mathrm{WT}^{20-}$ 22. In our study, according to the final histopathological diagnoses, PMA and WT were diagnosed in $48.6 \%$ and $30.8 \%$ of the patients, respectively. These data are compatible with the literature. According to the current literature, the most common malignant type is mucoepidermoid carcinoma ${ }^{20}$. In accordance with the literature, in the present study, the most common malignant tumor based on the final histopatological diagnoses were mucoepidermoid carcinoma, followed by adenoid cystic carcinoma.

The sensitivity and specificity of the preoperative FNAC reported in the literature vary in different populations ${ }^{23}$. In the current literature, the specificity and sensitivity rates of the preoperative FNAC are reported to range from $56 \%$ to $100 \%$ and from $57 \%$ to $98 \%$, respectively ${ }^{11,12}$. Schmidt et al. ${ }^{24}$ found the sensitivity and specificity rates of the preoperative FNAC as $76 \%$ and $97 \%$, respectively. Tryggvason et al. ${ }^{25}$ investigated the performance of the preoperative FNAC in the assessment of salivary gland tumors and reported sensitivity (85.7\%), specificity (99.5\%), and accuracy $(95.4 \%)$ rates as indicated. In another study, the false-positive rate ranged from $0 \%$ to $12.3 \%{ }^{26}$. There can be several reasons for these varying rates. There are different opinions across medical centers that perform FNAC. Also, technical differences exist such as by whom FNAC should be performed or whether it should be performed under USG guidance. In our tertiary care center, FNAC is performed with USG guidance as a standard procedure. Consistent with the literature, sensitivity (59.09\%), specificity (97.85\%), and accuracy $(93.75 \%)$ rates, PPV (76.47\%), and NPV (95.29) were calculated for the preoperative FNAC results.

About $80 \%$ of salivary gland tumors are benign ${ }^{2}$. The most common tumors encountered in clinical practice are PMA and $\mathrm{WT}^{20,21}$. Çomoğlu et al. ${ }^{21}$ found that sensitivity, specificity, PPV, and NPV of the preoperative FNAC for benign tumors were $92.38 \%, 80.64 \%$, 95.87\%, and $68.49 \%$, respectively. In our study, sensitivity, specificity, accuracy, PPV, and NPV of the preoperative FNAC for PMA were found as $94.06 \%, 94.34 \%, 94.23 \%$, $94.06 \%$, and $94.39 \%$, respectively. For WT, sensitivity (81.25\%), specificity (91.67\%), and accuracy (88.46\%) rates, and PPV (81.25\%), and NPV (91.67\%) were as indicated. Our results were compatible with the current literature. PMA and WT constitute an important percentage 
across salivary gland neoplasms in clinical practice (79.4\% of the cases in our study). PPV and NPV found for PMA and WT separately show that the agreements between the preoperative FNAC results and final histopathological diagnoses are quite high. Cytologic evaluation methods according to pre-MSRSGC era dichotomous benign/malignant classification seem sufficient for identifying benign cases. However, due to the overlap between salivary gland histopathologies, cytology is often indeterminate for identifying benign lesions. Diagnoses of oncocytoma, monomorphic adenoma, basal cell adenoma, myoepithelioma, etc. are difficult to ascertain based on cytology alone. This uncertainty is well characterized by the MSRSGC ${ }^{15}$. Also, the MSRSGC recommends usual clinical management options for each category ${ }^{15}$. In comparison, pre-MSRSGC era dichotomous benign/malignant classification appears less precise, thus less likely to influence patient management and decision-making than the MSRSGC. The impact of our results, though being meaningful, is limited as compared to those that differentiate the indeterminate cytologies from the "benign" category.

As for determining the "malignant" category, we think that pre-MSRSGC era dichotomous benign/ malignant classification is insufficient to make a differential diagnosis. The sensitivity rate we reported for the diagnosis of malignancy remains low, which is consistent with the literature ${ }^{26,27}$. Considering this, a standard method is required for the preoperative FNAC examination. The MSRSGC, which aims to standardize the cytologic examination and reporting of salivary gland lesions, consists of six-tiered classification rather than a dichotomous "yes/no" system ${ }^{15}$. Each category of the MSRSGC is associated with an implied risk of malignancy ranging from $<5 \%$ to $>90 \% \quad(\text { Table } 5)^{15}$. The MSRSGC specifies malignancy risk in two categories even for benign preoperative FNAC results ${ }^{15}$. In the category $4 a$ and $4 \mathrm{~b}$ of the MSRSGC, a malignancy risk of up to $5 \%$ and $35 \%$ are reported, respectively ${ }^{15}$.
However, the risks of malignancy in categories 5 and 6 of the MSRSGC are $60 \%$ and $>90 \%$, respectively ${ }^{15}$. Based on the comparative PPVs noted in the present study, we can argue that the MSRSGC has a much greater PPV. The preoperative FNAC results have a great importance because the patients are informed during the preoperative period. The accuracy of the test and the information given about malignancy risk are the most important criteria for patient management and decision-making. Thus, we think that the preoperative FNAC results examined according to the MSRSGC may be more efficient in patient management and decision-making.

It is noteworthy that tumor size is associated with the sensitivity rates of the preoperative FNAC. Altin et al. ${ }^{27}$ found sensitivity rates of the preoperative FNAC as $54.54 \%$ and $77.77 \%$ in tumors smaller, and larger than $2 \mathrm{~cm}$, respectively. We found that the agreement between the preoperative FNAC results, and final histopathological diagnoses was lower in patients with tumor sizes of $\geq 20 \mathrm{~mm}$. Especially in cystic lesions, if the sample is taken from the core and does not contain any tissue from the cortex, the possibility of having necrotic material in the aspirate is high. Therefore, erroneous results may occur $^{28}$. We found low agreement between the preoperative FNAC results and final histopathological diagnoses in tumors with cystic features. The nature and size of tumors seem to be the factors affecting preoperative FNAC examined according to pre-MSRSGC era dichotomous benign/malignant classification. Considering this effect, we think that preoperative FNAC results reporting the risk of malignancy may be more appropriate in terms of patient management and decision-making.

The present study has some limitations because of its retrospective design. Some variations may have occurred in the interpretation of the findings because the preoperative FNAC samples may have been examined by different pathologists 
S. Yildiz et al. Fine-Needle Aspiration Cytology of Salivary Gland Tumors Before the Milan System: Ten Years of Experience at a Tertiary Care Center in Turkey

during the 10-year study period. As another negative impact of the retrospective nature of the study, we could only evaluate FNAC results according to pre-MSRSGC era dichotomous benign/malignant classification. Re-examining the preoperative FNAC results included in this study according to the MSRSGC criteria could yield more valuable results. However, due to the low incidence of salivary gland tumors, a longer period is required to build a large sample size in such a study. Therefore, these limitations can be considered inevitable.

\section{CONCLUSION}

In conclusion, based on the evaluation of large case series collected over a long span, the preoperative cytologic examination according to pre-MSRSGC era dichotomous benign/malignant classification seems to be insufficient. Considering our 10 years of experience, we believe that the MSRSGC may contribute to patient management and decision-making by increasing the efficacy and the accuracy rates of FNAC.

\section{REFERENCES}

1. Batsakis JG. Tumors of the Head and Neck. $2^{\text {nd }}$ ed. Baltimore, MD: Williams \& Wilkins Co; 1979.

2. Nagler RM, Laufer D. Tumors of the major and minor salivary glands: review of 25 years of experience. Anticancer Res. 1997; 17:701-70. PMID: 9066605.

3. Ito FA, Ito K, Vargas PA, de Almeida OP, Lopes MA. Salivary gland tumors in a Brazilian population: a retrospective study of 496 cases. Int J Oral Maxillofac Surg. 2005;34:533-6. [CrossRef]

4. Ali NS, Akhtar S, Junaid M, Awan S, Aftab K. Diagnostic accuracy of fine needle aspiration cytology in parotid lesions. ISRN Surg. 2011;721525. [CrossRef]

5. Mavec P, Eneroth CM, Franzen S, Moberger G, Zajicek J. Aspiration biopsy of salivary gland tumours. Correlation of cytologic reports from 652 aspiration biopsies with clinical and histologic findings. Acta Otolaryngol. 1964;58:471-84. [CrossRef]

6. Thoeny HC. Imaging of salivary gland tumours. Cancer Imaging. 2007;7:52-62. [CrossRef]

7. Rossi ED, Wong LQ, Bizzarro T, et al. The impact of FNAC in the management of salivary gland lesions: institutional experiences leading to a risk-based classification scheme. Cancer Cytopathol. 2016;124:388-96. [CrossRef]

8. Ramírez-Pérez F, González-García R, Hernández-Vila C, Monje-Gil F, Ruiz-Laza R. Is fine-needle aspiration a reliable tool in the diagnosis of malignant salivary gland tumors? J Craniomaxillofac Surg. 2017;45:1074-7. [CrossRef]

9. Gudmundsson JK, Ajan A, Abtahi J. The accuracy of fineneedle aspiration cytology for diagnosis of parotid gland masses: a clinicopathological study of 114 patients. J Appl Oral Sci. 2016;24:561-7. [CrossRef]

10. Barnes L, Eveson JW, Reichart P, Sidransky D, editors. World Health Organisation Classification of Tumours. Pathology and Genetics of Head and Neck Tumours. Lyon, France: IARC Press; 2005.

11. Que Hee CG, Perry CF. Fine-needle aspiration cytology of parotid tumours: is it useful? ANZ J Surg. 2001;71:345-8. [CrossRef]

12. Cohen EG, Patel SG, Lin O, et al. Fine-needle aspiration biopsy of salivary gland lesions in a selected patient population. Arch Otolaryngol Head Neck Surg. 2004; 130:773-8. [CrossRef]

13. Shetty A, Geethamani V. Role of fine-needle aspiration cytology in the diagnosis of major salivary gland tumors: a study with histological and clinical correlation. J Oral Maxillofac Pathol. 2016;20:224-9. [CrossRef]

14. Barbarite E, Puram SV, Derakhsan A, Rossi ED, Faquin WC, Varvares MA. A call for universal acceptance of the Milan system for reporting salivary gland cytopathology. Laryngoscope. 2020;130:80-5. [CrossRef]

15. Rossi ED, Faquin WC. The Milan System for Reporting Salivary Gland Cytopathology (MSRSGC): An international effort toward improved patient carewhen the roots might be inspired by Leonardo da Vinci. Cancer Cytopathol. 2018;126:756-66. [CrossRef]

16. Griffith CC, Pai RK, Schneider F, et al. Salivary gland tumor fine needle aspiration cytology: a proposal for a risk stratification classification. Am J Clin Pathol. 2015;143:839-53. [CrossRef]

17. Layfield LJ, Baloch ZW, Hirschowitz SL, Rossi ED. Impact on clinical follow-up of the Milan System for salivary gland cytology: a comparison with a traditional diagnostic classification. Cytopathology. 2018;29:335-42. [CrossRef]

18. Rossi ED, Faquin WC, Baloch Z, et al. The Milan System for reporting salivary gland cytopathology: analysis and suggestions of initial survey. Cancer Cytopathol. 2017;125:757-66. [CrossRef]

19. Rohilla M, Singh P, Rajwanshi A, et al. Three-year cytohistological correlation of salivary gland FNA cytology at a tertiary center with the application of the Milan system for risk stratification. Cancer Cytopathol. 2017;125:767-75. [CrossRef]

20. Takahama A, De Almeida OP, Kowalski LP. Parotid neoplasms: analysis of 600 patients attended at a single institution. Braz J Otorhinolaryngol. 2009;75:497-501. [CrossRef]

21. Comoglu S, Ozturk E, Celik M, et al. Comprehensive analysis of parotid mass: a retrospective study of 369 cases. Auris Nasus Larynx. 2018;45:320-7. [CrossRef]

22. Andreasen S, Therkildsen MH, Bjфrndal K, Hom $\phi$ e P. Pleomorphic adenoma of the parotid gland 1985-2010: A Danish nationwide study of incidence, recurrence rate, and malignant transformation. Head Neck. 2016;38:E1364-9. [CrossRef]

23. Naz S, Hashmi AA, Khurshid A, et al. Diagnostic role of fine needle aspiration cytology (FNAC) in the evaluation of salivary gland swelling: an institutional experience. BMC Res Notes. 2015;8:101. [CrossRef] 
24. Schmidt RL, Hall BJ, Wilson AR, Layfield LJ. A systematic review and meta-analysis of the diagnostic accuracy of fine-needle aspiration cytology for parotid gland lesions. Am J Clin Pathol. 2011;136:45-59. [CrossRef]

25. Tryggvason G, Gailey MP, Hulstein SL, et al. Accuracy of fine-needle aspiration and imaging in the preoperative workup of salivary gland mass lesions treated surgically. Laryngoscope. 2013;123:158-63. [CrossRef]

26. Arul P, Akshatha C, Masilamani S, Jonathan S. Diagnosis of salivary gland lesions by fine needle aspiration cytology and its histopathological correlation in a tertiary care center of Southern India. J Clin Diagn Res.
2015;9:EC07-10. [CrossRef]

27. Altin F, Alimoglu Y, Acikalin RM, Yasar H. Is fine needle aspiration biopsy reliable in the diagnosis of parotid tumors? Comparison of preoperative and postoperative results and the factors affecting accuracy. Braz J Otorhinolaryngol. 2019;85:275-81. [CrossRef]

28. Al-Khafaji BM, Nestok BR, Katz RL. Fine-needle aspiration of 154 parotid masses with histologic correlation: tenyear experience at the University of Texas M. D. Anderson Cancer Center. Cancer. 1998;84:153-9. [CrossRef] 